\title{
Evaluating technology-enhanced learning: A comprehensive framework
}

\section{Appendices}

Appendix 1. Identification of key quality domains ......................................................... 1

Matrix showing presence of quality domains present in each evaluation instrument ............. 1

Final quality domains included in instruments ................................................................ 2

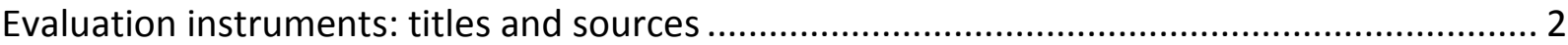

Appendix 2. Evaluation of Technology-Enhanced Learning Materials (ETELM) ......................... 3

Evaluation of Technology-Enhanced Learning Materials: Learner Perceptions (ETELM-LP) ...... 4

Evaluation of Technology-Enhanced Learning Materials: Instructor Perceptions (ETELM-IP) ... 6

Evaluation of Technology-Enhanced Learning Materials: Learner Perceptions - Short Form

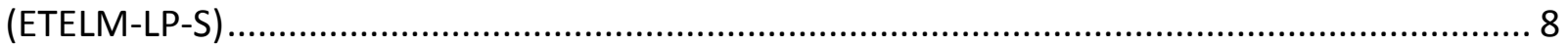




\section{Appendix 1. Identification of key quality domains}

This appendix documents key steps in the process of developing instruments for capturing the perceptions and experiences of learners and instructors following their participation in a TEL course, namely the identification of key quality domains to be reflected in these instruments.

Matrix showing presence of quality domains present in each evaluation instrument

\begin{tabular}{|c|c|c|c|c|c|c|c|c|c|c|c|c|}
\hline Quality Domain & 1* & $2^{*}$ & 3 & 4 & 5 & 6 & 7 & 8 & 9 & 10 & 11 & 12 \\
\hline $\begin{array}{l}\text { Course Overview / } \\
\text { Introduction / Orientation }\end{array}$ & $\mathrm{X}$ & & $\mathrm{X}$ & $X$ & & & $x$ & & & $\mathrm{X}$ & $\mathrm{X}$ & \\
\hline Learning Objectives & $X$ & & & & & $X$ & & & $X$ & $X$ & $X$ & \\
\hline $\begin{array}{l}\text { Student Assessment \& } \\
\text { Feedback }\end{array}$ & $X$ & $\mathrm{X}$ & $\mathrm{X}$ & $\mathrm{X}$ & $X$ & $\mathrm{X}$ & $\mathrm{X}$ & $\mathrm{X}$ & & & $X$ & $x$ \\
\hline Instructional Design & $\mathrm{X}$ & $X$ & $\mathrm{X}$ & $X$ & $\mathrm{X}$ & $\mathrm{X}$ & $X$ & $X$ & & $X$ & $\mathrm{X}$ & \\
\hline $\begin{array}{l}\text { Communication, Interaction, } \\
\text { \& Collaboration }\end{array}$ & $X$ & $X$ & & $X$ & & $X$ & $X$ & $X$ & $X$ & & $X$ & $\mathrm{X}$ \\
\hline $\begin{array}{l}\text { Course Technology } \\
\text { (Innovation, Technical } \\
\text { Support) }\end{array}$ & $X$ & $X$ & $X$ & $X$ & $X$ & & & $X$ & $X$ & & & $\mathrm{X}$ \\
\hline Web Design, Organization & $\mathrm{X}$ & $\mathrm{X}$ & $\mathrm{X}$ & & $\mathrm{X}$ & $X$ & $\mathrm{X}$ & $\mathrm{X}$ & $\mathrm{X}$ & $\mathrm{X}$ & $X$ & \\
\hline Learner Support \& Resources & $\mathrm{X}$ & $\mathrm{X}$ & & $X$ & $\mathrm{X}$ & $\mathrm{X}$ & & $X$ & $X$ & $X$ & $X$ & \\
\hline $\begin{array}{l}\text { Development, Maintenance \& } \\
\text { Institutional Support }\end{array}$ & & $X$ & $X$ & & & & & & $X$ & & & $\mathrm{X}$ \\
\hline $\begin{array}{l}\text { Instructor Support (i.e., helps } \\
\text { for faculty) }\end{array}$ & & $X$ & & $X$ & & & & & & & & \\
\hline $\begin{array}{l}\text { Course Evaluation, } \\
\text { Continuous Improvement }\end{array}$ & & $X$ & & $X$ & $X$ & $X$ & & X & $X$ & $X$ & & \\
\hline Instructor Presence & & & & & & & $X$ & & & & & X \\
\hline
\end{tabular}

* Instruments 1 and 2 are widely accepted as quality standards in mainstream education, and were used as the starting point for this matrix. 
Final quality domains included in instruments

Numbers in parentheses indicate order in final instrument

- Course Overview, Introduction, Organization (1)

- Learning Objectives (Competencies) (2)

- Student Assessment and Feedback (7)

- Instructional design / Web design (4)

- Communication, Interaction, and Collaboration (5)

- Technology issues (3)

- Learner Support / Instructor Support (9)

- Course Evaluation, Continuous Improvement (8)

- Face-to-face / Blended Elements (6)

\section{Evaluation instruments: titles and sources}

All websites confirmed 19 September 2014

1. Quality Matters: Quality Matters Higher Education Rubric. Available at: https://www.qualitymatters.org/rubric.

2. Online Learning Consortium (formerly the Sloan Consortium): Quality Scorecard for the Administration of Online Education Programs. Available at: http://onlinelearningconsortium.org/olcscorecard

3. Monterey Institute for Technology and Education: Online Course Evaluation Project. Available at: http://www.montereyinstitute.org/pdf/OCEP\%20Evaluation\%20Categories.pdf.

4. Appleton eSchool: Online Program Perceiver Instrument (OPPI). Presented in: Evaluating Online Learning: Challenges and Strategies for Success. Washington, D.C.: U.S. Department of Education; 2008 (http://www2.ed.gov/admins/lead/academic/evalonline/index.html).

5. Cal-State Chico: Rubric for Online Instruction. Available at: http://www.csuchico.edu/roi/.

6. Illinois Online Network (ION) and University of Illinois: Quality Online Course Initiative. Available at: http://www.ion.uillinois.edu/initiatives/qoci/.

7. Central Michigan University: Quality Assurance Checklist. Available at: http://global.cmich.edu/cid/quality-checklist.aspx.

8. U. Souther Mississippi: Online Course Development Guide and Rubric. Available at: http://www.usm.edu/lec/wp-content/uploads/2013/10/LEC Online course rev2-3.pdf.

9. Michigan Community Colleges: Online Course Development Guidelines and Rubric. Available at: http://www.mccvlc.org/ staff/content.cfm?ID=108.

10. Clayton R. Wright (Grant MacEwan College): Criteria for Evaluating the Quality of Online Courses. Available at: http://elearning.typepad.com/thelearnedman/ID/evaluatingcourses.pdf.

11. Western Carolina: Online Course Assessment Tool. Available at: https://www.wcu.edu/WebFiles/PDFs/facultycenter OCAT v2.0 25apr07.pdf.

12. Thomas J. Tobin (Southern Illinois University): Checklist for Online Interactive Learning. Available at: http://www.westga.edu/ distance/ojdla/summer72/tobin72.html. 


\section{Appendix 2. \\ Evaluation of Technology-Enhanced Learning Materials (ETELM)}

\section{Notes for those adopting or adapting one or more of these instruments}

\section{Purpose}

- The primary purpose of these instruments is to obtain formative feedback from students and instructors that can be used to improve the course.

- The Learner and Instructor instruments provide complementary information, and would typically be used together, although they could be used separately.

\section{Administration}

- Questions may be administered using electronic tools (course evaluation software, learning management systems, or survey tools) or paper.

- Some TEL courses do not require ongoing instructor involvement once they are developed (e.g., stand-alone online modules). The Instructor form applies equally to such courses, but completion of the form should be delayed until after several students have completed the course (so that the instructor has had a chance to receive questions and feedback from students).

Scoring and psychometrics

- All quantitative items use a 7-point Likert scale ( 1 = strongly disagree; 7 = strongly agree).

- Each item is independent and important in its own right; we would not expect uniform or consistent results from one item to the next (a course might have great instructions and navigation but poor educational activities). As such, calculating an overall score or subscores would not be meaningful. For the same reason, psychometric measures such as Cronbach's alpha and factor analysis will be of little value.

- Given that participants experiences would be reasonably expected to differ, psychometric measures such as inter-rater reliability would also be of little value for most items.

Modification and adaptation

- Other terms may be substituted for "course" (e.g., "module", "session", or "tutorial") as appropriate.

- New items may be added as needed, according to local needs.

- We discourage the deletion of items. Implementers should ideally use all existing items, both to allow for a holistic evaluation of the course and to allow for cross-course comparisons. However, since items are independent, dropping one or more would only impact that specific item (i.e., it would not invalidate the interpretation of the remaining questions).

- The number of response options could be changed (e.g., to a five-point or nine-point scale) to align with local practices. However, the response anchors of "strongly disagree" and "strongly agree" should not be changed. Also, in the absence of local precedents the use of the sevenpoint scale is preferred since it will facilitate cross-course comparisons. 


\section{Evaluation of Technology-Enhanced Learning Materials: Learner Perceptions (ETELM-LP) \\ An instrument to assess learner perceptions after participating in an online course}

Instructions

Please indicate your agreement with each of the statements below. If you give any item a 1 (strongly disagree) or 7 (strongly agree) please be sure to comment on this at the end of the survey.

\begin{tabular}{|c|c|c|c|c|c|c|c|}
\hline \multirow{2}{*}{$\begin{array}{l}\text { How well do you agree with the following? } \\
\text { 1. Instructions provided a good introduction to the course (e.g., how to } \\
\text { get started, where to find various course components, how to obtain } \\
\text { technical support if needed, etc.). }\end{array}$} & \multicolumn{4}{|c|}{$\begin{array}{l}\text { Strongly } \\
\text { disagree }\end{array}$} & \multicolumn{3}{|c|}{$\begin{array}{r}\text { Strongly } \\
\text { agree }\end{array}$} \\
\hline & 1 & 2 & 3 & 4 & 5 & 6 & 7 \\
\hline 2. Course objectives, expectations, and policies were clearly stated. & 1 & 2 & 3 & 4 & 5 & 6 & 7 \\
\hline 3. The course was well organized. & 1 & 2 & 3 & 4 & 5 & 6 & 7 \\
\hline 4. Course objectives were relevant to my needs. & 1 & 2 & 3 & 4 & 5 & 6 & 7 \\
\hline $\begin{array}{l}\text { 5. Navigation of the technology-based components of the course was } \\
\text { logical, consistent, and efficient. }\end{array}$ & 1 & 2 & 3 & 4 & 5 & 6 & 7 \\
\hline 6. The course technologies and media supported the learning objectives. & 1 & 2 & 3 & 4 & 5 & 6 & 7 \\
\hline $\begin{array}{l}\text { 7. This course required inappropriately high technology skills. (negative } \\
\text { answer is better; if agree, please explain below) }\end{array}$ & 1 & 2 & 3 & 4 & 5 & 6 & 7 \\
\hline $\begin{array}{l}\text { 8. I had significant computer / technical problems during this course. } \\
\text { (negative answer is better; if agree, please explain below) }\end{array}$ & 1 & 2 & 3 & 4 & 5 & 6 & 7 \\
\hline $\begin{array}{l}\text { 9. The educational activities encouraged engagement with course } \\
\text { materials / content. }\end{array}$ & 1 & 2 & 3 & 4 & 5 & 6 & 7 \\
\hline $\begin{array}{l}\text { 10. The educational activities promoted achievement of the course } \\
\text { objectives. }\end{array}$ & 1 & 2 & 3 & 4 & 5 & 6 & 7 \\
\hline 11. There was a strong instructor presence / personal touch in the course. & 1 & 2 & 3 & 4 & 5 & 6 & 7 \\
\hline $\begin{array}{l}\text { 12. Educational activities encouraged interaction and collaboration with } \\
\text { other participants. } \\
\text { [Omit if there was not a collaborative element in the course] }\end{array}$ & 1 & 2 & 3 & 4 & 5 & 6 & 7 \\
\hline $\begin{array}{l}\text { 13. Requirements for interaction and collaboration with other } \\
\text { participants were clearly articulated. } \\
\text { [Omit if there was not a collaborative element in the course] }\end{array}$ & & 2 & 3 & 4 & 5 & 6 & 7 \\
\hline $\begin{array}{l}\text { 14. The course effectively blended online and face-to-face elements. } \\
\text { [Omit if there was not a face-to-face element in the course] }\end{array}$ & & 2 & 3 & 4 & 5 & 6 & 7 \\
\hline $\begin{array}{l}\text { 15. Face-to-face activities contributed meaningfully toward achieving the } \\
\text { course learning objectives. } \\
\text { [Omit if there was not a face-to-face element in the course] }\end{array}$ & & 2 & 3 & 4 & 5 & 6 & 7 \\
\hline $\begin{array}{l}\text { 16. Assessments (e.g. tests and self-assessments) were appropriate for } \\
\text { the course objectives, content, and activities. } \\
\text { [Omit if there were no assessment opportunities in the course] }\end{array}$ & & 2 & 3 & 4 & 5 & 6 & 7 \\
\hline $\begin{array}{l}\text { 17. I had sufficient opportunity to assess and reflect upon my learning } \\
\text { progress. }\end{array}$ & & 2 & 3 & 4 & 5 & 6 & 7 \\
\hline 18. I received adequate feedback on my learning progress. & 1 & 2 & 3 & 4 & 5 & 6 & 7 \\
\hline $\begin{array}{l}\text { 19. I had sufficient opportunity to evaluate / provide feedback on the } \\
\text { course. }\end{array}$ & & 2 & 3 & 4 & 5 & 6 & 7 \\
\hline
\end{tabular}




\begin{tabular}{|l|lllllll|}
\hline \multicolumn{1}{|c|}{ How well do you agree with the following? } & $\begin{array}{l}\text { Strongly } \\
\text { disagree }\end{array}$ & \multicolumn{4}{c|}{$\begin{array}{c}\text { Strongly } \\
\text { agree }\end{array}$} \\
\hline $\begin{array}{l}\text { 20. I received adequate support for any technical issues encountered } \\
\text { during this course. }\end{array}$ & 1 & 2 & 3 & 4 & 5 & 6 & 7 \\
\hline $\begin{array}{l}\text { 21. I received adequate support for any questions or concerns I had about } \\
\text { my learning. }\end{array}$ & 1 & 2 & 3 & 4 & 5 & 6 & 7 \\
\hline $\begin{array}{l}\text { 22. I encountered culture- or language-related problems. (negative } \\
\text { answer is better; if agree, please explain below) }\end{array}$ & 1 & 2 & 3 & 4 & 5 & 6 & 7 \\
\hline $\begin{array}{l}\text { 23. I invested enough time and energy to meet / exceed the course } \\
\text { expectations. }\end{array}$ & 1 & 2 & 3 & 4 & 5 & 6 & 7 \\
\hline 24. This course will change my practice. & 1 & 2 & 3 & 4 & 5 & 6 & 7 \\
\hline 25. The overall quality of this course was excellent. & 1 & 2 & 3 & 4 & 5 & 6 & 7 \\
\hline 26. The overall effectiveness of the instructor was excellent. & 1 & 2 & 3 & 4 & 5 & 6 & 7 \\
\hline
\end{tabular}

The most helpful part of feedback is specific suggestions to improve the course. Please take a few minutes to share your ideas.

27. How could the quality of the course be improved? What would you keep the same? What would you change, remove, or add? Please describe and explain.

28. Overall, what elements of this course most contributed to your excitement and engagement as a learner? What could have been done to improve your engagement? Please describe and explain.

29. Is there anything else you'd like to share about your experience in this course? If so, please describe and explain. 


\section{Evaluation of Technology-Enhanced Learning Materials: Instructor \\ Perceptions (ETELM-IP) \\ An instrument to assess instructor perceptions after teaching an online course}

\section{Instructions}

Please indicate your agreement with each of the statements below. Answer questions using your judgment of participants' experiences, unless otherwise noted. If you give any item a 1 (strongly disagree) or 7 (strongly agree) please be sure to comment on this at the end of the survey.

\begin{tabular}{|c|c|c|c|c|c|c|c|}
\hline How well do you agree with the following? & & rong & & & & & \\
\hline $\begin{array}{l}\text { 1. Instructions provided a good introduction to the course (e.g., } \\
\text { participants did not have obvious questions about how to get started, } \\
\text { where to find various course components, how to obtain technical } \\
\text { support if needed, etc.). }\end{array}$ & 1 & 2 & & 4 & 5 & 6 & 7 \\
\hline 2. Course objectives were relevant to participant needs. & 1 & 2 & 3 & 4 & 5 & 6 & 7 \\
\hline $\begin{array}{l}\text { 3. Navigation of the technology-based components of the course was } \\
\text { logical, consistent, and efficient. }\end{array}$ & 1 & 2 & 3 & 4 & 5 & 6 & 7 \\
\hline 4. The course technologies and media supported the learning objectives. & 1 & 2 & 3 & 4 & 5 & 6 & 7 \\
\hline $\begin{array}{l}\text { 5. This course required that participants possess inappropriately high } \\
\text { computer skills. } \\
\text { (negative answer is better; if agree, please explain below) }\end{array}$ & 1 & 2 & 3 & 4 & 5 & 6 & 7 \\
\hline $\begin{array}{l}\text { 6. The educational activities encouraged participants' engagement with } \\
\text { course materials / content. }\end{array}$ & 1 & 2 & 3 & 4 & 5 & 6 & 7 \\
\hline $\begin{array}{l}\text { 7. The educational activities promoted participants' achievement of the } \\
\text { course objectives. }\end{array}$ & 1 & 2 & 3 & 4 & 5 & 6 & 7 \\
\hline $\begin{array}{l}\text { 8. I was able to contribute a personal presence / personal touch during } \\
\text { the course's development and/or delivery. }\end{array}$ & 1 & 2 & 3 & 4 & 5 & 6 & 7 \\
\hline $\begin{array}{l}\text { 9. Educational activities encouraged participants' interaction and } \\
\text { collaboration. } \\
\text { [Omit if there was not a collaborative element in the course] }\end{array}$ & 1 & 2 & 3 & 4 & 5 & 6 & 7 \\
\hline $\begin{array}{l}\text { 10. The course effectively blended online and face-to-face elements. } \\
\text { [Omit if there was not a face-to-face element in the course] }\end{array}$ & 1 & 2 & 3 & 4 & 5 & 6 & 7 \\
\hline $\begin{array}{l}\text { 11. Face-to-face activities contributed meaningfully toward achieving the } \\
\text { course learning objectives. } \\
\text { [Omit if there was not a face-to-face element in the course] }\end{array}$ & 1 & 2 & 3 & 4 & 5 & 6 & 7 \\
\hline $\begin{array}{l}\text { 12. Assessments (e.g. tests and self-assessments) were appropriate for } \\
\text { the course objectives, content, and activities. } \\
\text { [Omit if there were no assessment opportunities in the course] }\end{array}$ & 1 & 2 & 3 & 4 & 5 & 6 & 7 \\
\hline $\begin{array}{l}\text { 13. Learner assessments and provision of feedback proceeded smoothly } \\
\text { (i.e., no unforeseen problems). } \\
\text { [Omit if there were no assessment opportunities in the course] }\end{array}$ & 1 & 2 & 3 & 4 & 5 & 6 & 7 \\
\hline 14. I plan to use learner feedback to improve the course. & 1 & 2 & 3 & 4 & 5 & 6 & 7 \\
\hline 15. The course will be easy to maintain and deliver again. & 1 & 2 & 3 & 4 & 5 & 6 & 7 \\
\hline $\begin{array}{l}\text { 16. It will be easy to re-use of all or part of the course materials in other, } \\
\text { future courses. }\end{array}$ & 1 & 2 & 3 & 4 & 5 & 6 & 7 \\
\hline 17. I had access to needed tools during course development and delivery. & 1 & 2 & 3 & 4 & 5 & 6 & 7 \\
\hline
\end{tabular}

Cook \& Ellaway. Evaluation of Technology-Enhanced Learning. Appendix 2. Page 6 Copyright $@ 2014$ Mayo Foundation 


\begin{tabular}{|c|c|c|c|c|c|c|c|c|}
\hline How well do you agree with the following? & \multicolumn{4}{|c|}{$\begin{array}{l}\text { Strongly } \\
\text { disagree }\end{array}$} & \multicolumn{4}{|c|}{$\begin{array}{r}\text { Strongly } \\
\text { agree }\end{array}$} \\
\hline $\begin{array}{l}\text { 18. I had significant computer / technical problems while developing or } \\
\text { delivering this course. (negative answer is better; if agree, please } \\
\text { explain below) }\end{array}$ & 1 & 2 & 3 & 4 & & 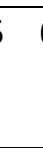 & 6 & 7 \\
\hline $\begin{array}{l}\text { 19. I received adequate support for any technical issues encountered } \\
\text { while developing and delivering this course. }\end{array}$ & 1 & 2 & 3 & 4 & & ( & 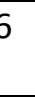 & 7 \\
\hline $\begin{array}{l}\text { 20. I was able to provide adequate support to students for questions or } \\
\text { concerns about their learning. }\end{array}$ & 1 & 2 & 3 & 4 & & & o & 7 \\
\hline 21. The course was a good use of time and resources. & 1 & 2 & 3 & $\angle$ & & & o & 7 \\
\hline 22. The overall quality of this course was excellent. & 1 & 2 & 3 & 4 & & & 6 & 7 \\
\hline
\end{tabular}

The most helpful part of feedback is specific suggestions to improve the course. Please take a few minutes to share your ideas.

23. What could have been done to improve the process of course development and implementation?

24. How could the quality of the course be improved? What would you keep the same? What would you change, remove, or add? Please describe and explain.

25. Overall, what elements of this course most contributed to your excitement and engagement as an instructor? What could have been done to improve your engagement? Please describe and explain.

26. Is there anything else you'd like to share about your experience in this course? If so, please describe and explain. 


\section{Evaluation of Technology-Enhanced Learning Materials: Learner Perceptions \\ - Short Form (ETELM-LP-S)}

An instrument to assess learner perceptions after participating in a brief online course/module that meets all of the following criteria:

- Course is anticipated to take less than 30 minutes to complete;

- Course employs limited interactivity and no collaboration with other students;

- Face-to-face elements are not present, or will be evaluated using other means.

Individual items from the ETELM-LP may be reinstated if needed.

Instructions

Please indicate your agreement with each of the statements below. If you give any item a 1 (strongly disagree) or 7 (strongly agree) please be sure to comment on this at the end of the survey.

\begin{tabular}{|c|c|c|c|c|c|c|c|}
\hline \multirow{2}{*}{$\begin{array}{l}\text { How well do you agree with the following? } \\
\text { ions provided a good introduction to the course (e.g., how to } \\
\text { ted, where to find various course components, how to obtain } \\
\text { l support if needed, etc.). }\end{array}$} & \multicolumn{4}{|c|}{$\begin{array}{l}\text { Strongly } \\
\text { disagree }\end{array}$} & \multicolumn{3}{|c|}{$\begin{array}{r}\text { Strongly } \\
\text { agree }\end{array}$} \\
\hline & 1 & 2 & & 4 & 5 & 6 & 7 \\
\hline 2. Course objectives, expectations, and policies were clearly stated. & 1 & 2 & 3 & 4 & 5 & 6 & 7 \\
\hline 3. Course objectives were relevant to my needs. & 1 & 2 & 3 & 4 & 5 & 6 & 7 \\
\hline $\begin{array}{l}\text { 4. Navigation of the technology-based components of the course was } \\
\text { logical, consistent, and efficient. }\end{array}$ & 1 & 2 & 3 & 4 & 5 & 6 & 7 \\
\hline 5. The course technologies and media supported the learning objectives. & 1 & 2 & 3 & 4 & 5 & 6 & 7 \\
\hline $\begin{array}{l}\text { 6. I had significant computer / technical problems during this course. } \\
\text { (negative answer is better; if agree, please explain below) }\end{array}$ & 1 & 2 & 3 & 4 & 5 & 6 & 7 \\
\hline $\begin{array}{l}\text { 7. The educational activities encouraged engagement with course } \\
\text { materials / content. }\end{array}$ & 1 & 2 & 3 & 4 & 5 & 6 & 7 \\
\hline $\begin{array}{l}\text { 8. The educational activities promoted achievement of the course } \\
\text { objectives. }\end{array}$ & 1 & 2 & 3 & 4 & 5 & 6 & 7 \\
\hline $\begin{array}{l}\text { 9. I had sufficient opportunity to assess and reflect upon my learning } \\
\text { progress. }\end{array}$ & 1 & 2 & 3 & 4 & 5 & 6 & 7 \\
\hline 10. I received adequate feedback on my learning progress. & 1 & 2 & 3 & 4 & 5 & 6 & 7 \\
\hline $\begin{array}{l}\text { 11. I received adequate support for any questions or concerns I had about } \\
\text { my learning. }\end{array}$ & 1 & 2 & 3 & 4 & 5 & 6 & 7 \\
\hline 12. This course will change my practice. & 1 & 2 & 3 & 4 & 5 & 6 & 7 \\
\hline 13. The overall quality of this course was excellent. & 1 & 2 & 3 & 4 & 5 & 6 & 7 \\
\hline 14. The overall effectiveness of the instructor was excellent. & 1 & 2 & 3 & 4 & 5 & 6 & 7 \\
\hline
\end{tabular}

The most helpful part of feedback is specific suggestions to improve the course. Please take a few minutes to share your ideas.

15. How could the quality of the course be improved? What would you keep the same? What would you change, remove, or add? Please describe and explain.

16. Overall, what elements of this course most contributed to your excitement and engagement as a learner? What could have been done to improve your engagement? Please describe and explain. 